\title{
Molecular spectrum and distribution of hemoglobinopathies in southwest of Iran: a seven-year retrospective study
}

\author{
Mina Ebrahimi ${ }^{1} \cdot$ Javad Mohammadi-as| $^{2} \cdot$ Fakher Rahim $^{1,3}$ \\ Received: 16 October 2019 / Accepted: 28 January 2020 / Published online: 17 February 2020 \\ (C) Springer-Verlag GmbH Germany, part of Springer Nature 2020
}

\begin{abstract}
Thalassemia is one of the most common inherited autosomal recessive disorders around the world. Over 200 mutations in the beta-globin gene and 70 mutations in the alpha-globin gene have been identified. This study aimed to assess a comprehensive prevalence of most frequent thalassemia mutations in Khuzestan Province, where is a belt of thalassemia in Iran. A total of 6946 subjects were enrolled for evaluating alpha-beta thalassemia from 2012 to 2018. In order to determine the silent mutations, subjects with microcytic hypochromic without anemia with normal $\mathrm{Hb}, \mathrm{HbA} 2$, and $\mathrm{HbF}$ were included too. Genomic DNA was extracted, and ARMS-PCR, Gap-PCR, and DNA sequencing were used to detect thalassemia mutations. Of 6946 individuals, just $880(12.6 \%)$ were normal, and $6066(87.3 \%)$ were the carrier for thalassemia. The most frequent phenotype was alpha thalassemia $(3984 ; 57.4 \%)$, followed by beta $(1429 ; 20.6 \%)$, and alpha-beta thalassemia $(653 ; 9.4 \%)$, respectively. The most frequent alpha mutation was $-3.7(68.6 \%)$, followed by $-\alpha(6.2 \%)$, Codon $19(2.9 \%)$, Poly A2 (2.7\%), and $-5 \mathrm{nt}(2.4 \%)$, respectively. In beta thalassemia, the more often mutations have been HbS (20.2\%), IVSI-I (11.3\%), Codon 36/37 (11.2\%), and IVSI-110 (7.4\%), respectively. Additional analysis showed that the most frequent genotypes in alpha and beta thalassemia were heterozygous carriers with $-3.7 \alpha(52.2 \%)$ and $\mathrm{HbS}(21.3 \%)$ mutations, respectively. The lowest $\mathrm{Hb}$ was found in heterozygote beta thalassemia carriers with IVSII- $1 \beta$ mutation $(11.6 \mathrm{~g} / \mathrm{dl})$. Our findings showed that the distribution of beta thalassemia mutations differs from other previous data reported from Khuzestan and other provinces. This study is useful for screening and preventing thalassemia.
\end{abstract}

Keywords Co-inheritance $\cdot$ Alpha thalassemia $\cdot$ Beta thalassemia $\cdot$ Mutations

\section{Introduction}

Highlights • Prevalence alpha, beta, and co-inheritance alpha-beta thalassemia in southwest of Iran

- Most thalassemia mutations and genotypes in southwest of Iran

- Comparing $\mathrm{Hb}$ level between different genotypes

Electronic supplementary material The online version of this article (https://doi.org/10.1007/s12308-020-00388-7) contains supplementary material, which is available to authorized users.

Fakher Rahim

bioinfo2003@gmail.com

1 Thalassemia and Hemoglobinopathy Research Center, Health Research Institute, Ahvaz Jundishapur University of Medical Sciences, Ahvaz, Iran

2 Department of Medical Genetics, School of Medicine, Ahvaz Jundishapur University of Medical Sciences, Ahvaz, Iran

3 Clinical Research development Unit, Golestan Hospital, Ahvaz Jundishapur University of Medical Sciences, Ahvaz, Iran
Thalassemia is one of the most common inherited autosomal recessive disorders around the world. Estimated nearly 30,000 children born each year with this disorder, and this has made thalassemia increasingly important [1]. The alpha-globin gene is localized in the telomeric region of chromosome $16(16 \mathrm{p}$ 13.3) and beta-globin gene cluster is located in chromosome $11[2,3]$. Mutation or deletion in alpha and beta genes, causing a decline or absence in the production of the globin chains. Depending on the type of mutations and their effects on globin gene expression, the severity of anemia varies from slight to severe. In the alpha-globin gene, non-deletional mutations (NDM) like $-3.7 \alpha$, by involving the different stages of gene expression, mRNA translation, and alpha-globin stability, produce a slighter phenotype than deletional mutations (DM). Mutation in beta genes by decreasing beta-globin mRNA stability affects mRNA processing and reduces beta chain synthesis [4]. In beta thalassemia, due to the reduction of beta- 
globin synthesis, the imbalance of the alpha-beta chains increases. Since free alpha-globins can not constitute tetramer, their accumulation in the cells causes damage cell surface, generating reactive oxygen species (ROS) and finally causing oxidative stress that promotes hemolysis. Macrophages in bone marrow, by phagocyting the precipitated erythroblasts, causes developing ineffective erythropoiesis. Extending ineffective erythropoiesis and hemolysis leads to splenomegaly, bone deformities, increase iron absorption, and metabolic disorder. Subjects with just one mutation in alpha or beta genes do not have a difference with healthy subjects and are identified just in the molecular examination [5, 6]. Nonrecognition of these carriers causes more prevalence of thalassemia.

The heterogeneity in thalassemia mutations has been the subject of intense debate within the scientific community. This has led to the proliferation of studies with contradictory findings of the thalassemia mutations and their prevalence around the world; these disagreements may be due to the different ethnicities and the low sample size. For example, the most reported mutations in alpha genes were DMs, whereas United Arab Emirates (UAE) reported the NDMs-like PollyA1 are more frequent [7-10]. These contradictory results are more seen in beta gene mutations; even in Iran, there has been a little agreement about beta thalassemia mutations spectrum. The most-reported mutations in beta genes in Iran are Codon 36/37 and I VS II-1 mutations; however, there are several differences reports [11-15]. Khuzestan Province in the southwest of Iran with a heterogeneous population is one of the most prevalent points of thalassemia in Iran and the Middle East. In order to evaluate the success of the thalassemia-preventing program and identifying common mutations in this region, several investigations were conducted, whose results indicated in addition to the above mutations, $\mathrm{HbS}$ has a high frequency in this province [16]. The aim of this survey was to investigate the most mutations in both alpha and beta genes and their association with $\mathrm{Hb}$ level.

\section{Materials and methods}

\section{Ethical statement of the study}

The study is base on the approval of the Medical Ethics Committee of Ahvaz Jundishapur University (reference number: Th-9808). The screening and identifying thalassemia were done according to the last updated National Thalassemia Prevention Guidelines in Iran provided in 2012.

\section{Study design and population}

The Khuzestan Province is a region with different ethnicities and one of the most centers of thalassemia in Iran. To evaluate the most prevalent thalassemia mutations in alpha and beta genes, and their effect on the phenotype of thalassemia, 6946 subjects were enrolled across 2012-2018. All participants were recruited to a private clinic for premarital screening.

\section{Inclusion criteria}

Accordance with the National Thalassemia Prevention Guidelines, subjects with mean cell volume (MCV) below $80(\mathrm{Fl})$, mean cell hemoglobin ( $\mathrm{MCH})$ below 27 (pg), or both have to be considered for evaluating their $\mathrm{HbA} 2$ level by column chromatography. The HbA2 level between 3.5 and $7 \%$ was considered as beta thalassemia carrier, and $>7 \%$ was suspected as hemoglobinopathies. In the heterozygote (minor), alpha thalassemia, MCV, and $\mathrm{MCH}$ have just reduced. In the current investigation to determine the silent mutations, subjects with microcytic hypochromic without anemia with normal $\mathrm{Hb}, \mathrm{HbA} 2$, and $\mathrm{HbF}$ were included too.

\section{Hematological analysis}

Blood samples were collected from among all subjects into ethylenediaminetetraacetate acid (EDTA) tubes. The cell blood counter (CBC) was conducted using the SYSMEX XN1000 (JAPAN) hematology analyzer. HbA, HbA2, and $\mathrm{HbF}$ were measured by $\mathrm{Hb}$ electrophoresis (Helena Laboratories).

\section{Genotyping analysis}

DNA was extracted from peripheral blood cells using MagCore-automated nucleic acid extraction (Switzerland). The purity and concentration of the extracted DNA were measured using the NanoDrop spectrophotometer (Thermo). Gappolymerase chain reaction (Gap-PCR) technique was used to detect common DMs in alpha genes. Point mutations in alpha and beta genes were detected by the amplification refractory mutation system (ARMS). The detecting mutation panel for both alpha and beta genes was shown in ESM Appendix 1. In cases that PCR could not detect common mutations, DNA sequencing by ABI-3130XL (USA) was used.

\section{Statistical analysis}

All analyses were carried out using SPSS version 24. The normalization of data has been checked by KolmogorovSmirnov. Kruskal-Wallis test was used to determine the correlation between genotype and $\mathrm{Hb}$ level with a $95 \%$ confidence interval (CI). Mann-Whitney test was used to compare means. The $P$ value of less than 0.05 was considered as significant statistically. 


\section{Results}

In this study, 6946 individuals, including 3473 (50.0\%) females, $3455(49.7 \%)$ males, and $18(0.3 \%)$ children, were investigated for thalassemia, of which just $880(12.6 \%)$ and the remainder, i.e., 6066 (87.3\%), respectively, were normal, and the carriers of thalassemia gene were defects. As shown in Table 1, the most frequent type of thalassemia was alpha thalassemia $(3984 ; 57.4 \%)$, followed by beta $(1429 ; 20.6 \%)$, and alpha-beta thalassemia $(653 ; 9.4 \%)$, respectively. Further analysis showed a significant difference in $\mathrm{Hb}$ and $\mathrm{MCV}$ when they were adjusted for gender $(P<0.001)$.

Post hoc analysis showed that the means of the hematological parameters, including $\mathrm{Hb}, \mathrm{MCV}$, and $\mathrm{MCH}$, were significantly lower in beta and alpha-beta thalassemia (Table 2). As expected, $\mathrm{HbA} 2$ and $\mathrm{HbF}$ were higher in beta and alpha-beta thalassemia carriers $(P<0.001)$ (Table 2). No significant differences were found between alpha thalassemia carriers compared with healthy subjects for $\mathrm{HbA} 2(P=0.815)$ and $\mathrm{HbF}$ $(P=0.491)$ (Table 2). After comparing different genotypes for $\mathrm{Hb}$ level with normal subjects, it was found that nine mutations in heterozygous caused a significant reduction in $\mathrm{Hb}$ level; of these, the lowest $\mathrm{Hb}$ was observed in subjects with a harboring IVSII-I mutation $(P<0.001)$ (Table 3$)$.

In an analysis of beta mutations, fifty mutations were detected, of which Hb-S (20.2\%), IVSI-1 (11.3\%), Codon36/37 $(11.2 \%)$, and IVSI-110 (7.4\%) were the more often mutations (Table 4). There are several rare detected mutations with less than $1 \%$ frequency, including -87 , Codon 30 , Codon 17 , IVSI-726, 30, $+20,+22$, IVSII-850, Codon 30 , Codon $41 /$ 42, Codon 27, IVSI-13, -71 (c > T), IVSI-108, Codon 26, IVSII-848, IVSII-849, IVSI-128, IVSII-II, $+1479,-56$, and unknown (ESM Appendix 2). The most detected genotypes in beta and alpha-beta thalassemia carriers were $\beta / \mathrm{HbS}(21.3 \%)$ and $-3.7 / \mathrm{S}(54.0 \%)$, respectively.

In alpha mutation analysis, forty-four mutations were identified, from these, -3.7 mutation with a frequency of $68.6 \%$ was the most prevalent, followed by $-\alpha(6.2 \%)$, Codon 19 (2.9\%), Polly A2 (2.7\%) and $-5 \mathrm{nt}(2.4 \%)$, respectively (Table 5). There were the rarest mutations with a frequency of less than $1 \%$ in alpha genes like PollyA4, Codon 142, and PollyA6 (ESM Appendix 2). The most frequent genotype in alpha thalassemia patients was $-3.7 / \alpha \alpha(52.2 \%)$.

Table 1 Genotypes frequency of patients

\begin{tabular}{lc}
\hline Genotype & Frequency (\%) \\
\hline Alpha-thalassemia & $3984(57.4 \%)$ \\
Beta-thalassemia & $1429(20.6 \%)$ \\
Alpha-beta thalassemia & $653(9.4 \%)$ \\
Normal & $880(12.6 \%)$ \\
Total & $6946(100.0 \%)$ \\
\hline
\end{tabular}

Table 2 Subgroup analysis of hematological parameters between different thalassemia phenotypes

\begin{tabular}{|c|c|c|c|c|}
\hline \multirow{2}{*}{$\begin{array}{l}\text { Patient genotypes } \\
\text { Normal }\end{array}$} & \multirow{2}{*}{$\begin{array}{l}\mathrm{Hb} \\
13.4\end{array}$} & \multirow[t]{2}{*}{ Sig } & \multicolumn{2}{|c|}{$95 \% \mathrm{CI}$ for difference } \\
\hline & & & Lower bound & Higher bound \\
\hline Alpha-thalassemia & 13.3 & 0.84 & -1.03 & 1.26 \\
\hline Beta-thalassemia & 12.6 & 0.22 & -0.5 & 2.13 \\
\hline Alpha-beta thalassemia & 14.8 & 0.083 & -3.05 & 0.18 \\
\hline Normal & $\mathrm{MCV}$ & Sig & $\begin{array}{r}95 \% \text { CI fo } \\
\text { Lower bound }\end{array}$ & $\begin{array}{l}\text { r difference } \\
\text { Higher bound }\end{array}$ \\
\hline Alpha-thalassemia & 77.4 & $P<001$ & 2.4 & 4.5 \\
\hline Beta-thalassemia & 68.4 & $P<001$ & 11.2 & 13.7 \\
\hline Alpha-beta thalassemia & 71.2 & $P<001$ & 8.2 & 11.2 \\
\hline Normal & $\mathrm{MCH}$ & Sig & $\begin{array}{r}95 \% \text { CI fo } \\
\text { Lower bound }\end{array}$ & $\begin{array}{l}\text { r difference } \\
\text { Higher bound }\end{array}$ \\
\hline Alpha-thalassemia & 25.0 & $P<001$ & 0.9 & 2.1 \\
\hline Beta-thalassemia & 22.6 & $P<001$ & 3.1 & 4.6 \\
\hline Alpha-beta thalassemia & 23.2 & $P<001$ & 2.4 & 4.2 \\
\hline Normal & $\mathrm{HbA} 2$ & Sig & $\begin{array}{r}95 \% \text { CI fo } \\
\text { Lower bound }\end{array}$ & $\begin{array}{l}\text { r difference } \\
\text { Higher bound }\end{array}$ \\
\hline Alpha-thalassemia & 2.7 & 0.815 & -0.458 & 0.582 \\
\hline Beta-thalassemia & 5.2 & $P<001$ & -2.97 & -1.78 \\
\hline Alpha-beta thalassemia & 4.3 & $P<001$ & -2.23 & -0.779 \\
\hline Normal & $\mathrm{HbF}$ & Sig & $\begin{array}{r}95 \% \text { CI fo } \\
\text { Lower bound }\end{array}$ & $\begin{array}{l}\text { r difference } \\
\text { Higher bound }\end{array}$ \\
\hline Alpha-thalassemia & 0.6 & 0.491 & -0.245 & 0.511 \\
\hline Beta-thalassemia & 1.7 & $P<001$ & -1.438 & -0.599 \\
\hline Alpha-beta thalassemia & 1.5 & 0.003 & -1.271 & -0.265 \\
\hline
\end{tabular}

\section{Discussion}

The present study was designed to determine the most prevalent type of thalassemia and mutations in Khuzestan Province, southwest of Iran. Based on the conducted studies, beta thalassemia is more prevalent in Iran and is more severe than alpha-thalassemia [17]. Prenatal diagnostic tests in Iran were established from 1997 to prevent beta thalassemia. For this, evaluating the rate of thalassemia and most mutations has led to a proliferation of studies in this field. Previously published studies are limited to investigating just one type of thalassemia or evaluating a small sample size in Khuzestan $[18,19]$. It has been demonstrated that in Khuzestan province, beta thalassemia is higher than the other provinces. However, it is in contrast with our finding that alpha-thalassemia is more prevalent [20] (Table 1).

After mutation analysis, our data revealed that five mutations, including $\mathrm{HbS}$, Codon 36/37, IVSI-1, IVSI-110, and 
Table 3 The mean $\mathrm{Hb}$ level in different genotypes comparing with normal genotype

\begin{tabular}{|c|c|c|c|c|c|c|c|}
\hline \multicolumn{8}{|c|}{$95 \%$ confidence interval } \\
\hline & Frequency & $\begin{array}{l}\text { Percentage } \\
(\%)\end{array}$ & $\begin{array}{l}\text { Hemoglobin } \\
(\mathrm{g} / \mathrm{dl})\end{array}$ & $\mathrm{SD}$ & Sig. & $\begin{array}{l}\text { Lower } \\
\text { bound }\end{array}$ & $\begin{array}{l}\text { Upper } \\
\text { bound }\end{array}$ \\
\hline Normal & 863 & & $13.1(7.7-18.4)$ & 1.6 & & & \\
\hline \multicolumn{8}{|c|}{ Alpha-thalassemia } \\
\hline$-3.7 /-3.7$ & 473 & $11.9 \%$ & $12.7(7.8-18.8)$ & 1.5 & $P<0.001$ & 0.251 & 0.628 \\
\hline$-\operatorname{med} / \alpha \alpha$ & 60 & $1.5 \%$ & $12.3(7.9-15.2)$ & 1.5 & $P<0.001$ & 0.375 & 1.253 \\
\hline \multicolumn{8}{|c|}{ Beta-thalassemia } \\
\hline $\begin{array}{c}\mathrm{N} / \mathrm{Cd} 6(\mathrm{Hb} \\
\mathrm{S})\end{array}$ & 208 & $20.3 \%$ & $13.8(7.5-18.6)$ & 1.8 & $P<0.001$ & -0.928 & -0.404 \\
\hline N/IVSI-I & 176 & $17.2 \%$ & $11.8(7.2-16.1)$ & 1.4 & $P<0.001$ & 1.058 & 1.605 \\
\hline $\mathrm{N} / \mathrm{Cd} 36-37$ & 177 & $17.3 \%$ & $11.7(9-15.1)$ & 1.3 & $P<0.001$ & 1.152 & 1.696 \\
\hline N/IVSI-110 & 109 & $10.6 \%$ & $12.2(7.6-15.2)$ & 1.5 & $P<0.001$ & 0.645 & 1.316 \\
\hline N/Fr8-9 & 74 & $7.2 \%$ & $11.8(9.3-19.6)$ & 1.3 & $P<0.001$ & 0.940 & 1.757 \\
\hline N/IVSII-I & 106 & $10.3 \%$ & $11.6(8.3-14.9)$ & 1.4 & $P<0.001$ & 1.171 & 1.863 \\
\hline $\mathrm{N} / \mathrm{Cd} 5$ & 47 & $4.6 \%$ & $11.7(9.4-15)$ & 1.4 & $P<0.001$ & 0.920 & 1.905 \\
\hline $\mathrm{N} /-25 \mathrm{~b}$ & 51 & $5 \%$ & $12.2(8.9-15.2)$ & 1.5 & $P<0.001$ & 0.469 & 1.425 \\
\hline
\end{tabular}

IVSII-1, account for over than $50 \%$ beta thalassemia mutations in our population (Table 4); this is in agreement with finding of Tosun et al.'s study in Turkey [21] while inconsistent with previous Iranian studies' results in a geographical difference, where IVSII-1 was most prevalent [11, 22, 23]. A survey conducted by Kiani et al. showed that Codon 36/ 37 is more frequent and different from other parts of Iran [14].

Table 4 An overview of the most frequent mutations in the beta gene and their phenotypes

\begin{tabular}{lccl}
\hline Beta-thalassemia mutations & Frequency & Percentage $(\%)$ & Phenotype \\
\hline HbS & 419 & 20.2 & $\beta^{0}$ \\
IVSI-1 & 234 & 11.3 & $\beta^{0}$ \\
Cd36-37 & 233 & 11.2 & $\beta^{0}$ \\
IVSI-110 & 154 & 7.4 & $\beta+$ \\
IVSII-1 & 143 & 6.9 & $\beta^{0}$ \\
Fr8-9 & 104 & 5.0 & $\beta^{0}$ \\
HbD & 81 & 3.9 & $\beta+$ \\
-25 del & 79 & 3.8 & $\beta+$ \\
-101 & 72 & 3.5 & $\beta+$ \\
Cd5 & 67 & 3.2 & $\beta^{0}$ \\
IVSI-6 & 53 & 2.6 & $\beta+$ \\
-88 & 48 & 2.3 & $\beta+$ \\
Cd39 & 44 & 2.1 & $\beta+$ \\
IVSI-5 & 43 & 2.1 & $\beta^{0}$ \\
IVSII-745 & 36 & 1.7 & $\beta+$ \\
Cd82-83 & 35 & 1.7 & $\beta+$ \\
Cd44 & 33 & 1.6 & $\beta^{0}$ \\
-28 & 28 & 1.4 & $\beta+$ \\
Initiation Cd & 20 & 1.0 & $\beta^{0}$ \\
\hline Cd. Cod & & & \\
\hline
\end{tabular}

$C d$, Codon
An explanation for this might be due to the difference in ethnic and smaller sample sizes. Compared with the other studies around the world, Chinese researchers reported that Codon $41 / 42$ mutation is more prevalent [24, 25].

Except for IVSI-110, other mutations develop $\beta^{0}$ phenotype, which in the heterozygous genotype significantly reduces $\mathrm{Hb}$ compared with normal subjects. It can be seen in Table 3, that the subjects with IVSII-1 heterozygote genotype had significantly lower $\mathrm{Hb}$ compared with the other genotypes. This finding supports the previous research that in coexisting alpha thalassemia with beta thalassemia or hemoglobinopathies, due to the reduced accumulation of free alphachains, the toxic effect decreases and reduces the severity of thalassemia [26-28].

$\mathrm{The} \mathrm{Hb} \mathrm{H}$ disease is an unstable form of $\mathrm{Hb}$, which is the result of the homozygote for NDMs or heterozygous for both DMs and NDMs [29]. Our findings demonstrated that more

Table 5 The most frequent alpha gene mutations

\begin{tabular}{lrrl}
\hline $\begin{array}{l}\text { Alpha-thalassemia } \\
\text { mutations }\end{array}$ & Frequency & Percentage (\%) & Phenotype \\
\hline-3.7 & 3169 & 68.6 & $\alpha+$ \\
$-\mathrm{a}$ & 288 & 6.2 & $\alpha+$ \\
Cd19 & 135 & 2.9 & $\alpha+$ \\
Polly A2 & 123 & 2.7 & $\alpha^{0}$ \\
$5 \mathrm{nt}$ & 109 & 2.4 & $\alpha+$ \\
- med- & 73 & 1.6 & $\alpha^{0}$ \\
-4.2 & 56 & 1.2 & $\alpha+$ \\
Anti 3.7 & 49 & 1.1 & $\alpha+$ \\
Initiation codon & 45 & 1.0 & $\alpha+$ \\
Not found & 350 & 7.6 & - \\
\hline
\end{tabular}


Table 6 Distribution type of thalassemia in various regions of Iran

\begin{tabular}{|c|c|c|c|c|}
\hline Area & Hemoglobinopathies & alpha-thalassemia & beta-thalassemia & Ref. \\
\hline North of Iran & & $-3.7 \alpha(44.9 \%)$ & IVSII-I (56.1\%) & {$[13,34]$} \\
\hline Northwest of Iran & & $-3.7 \alpha(51.7 \%)$ & $\begin{array}{l}\text { IVSII-1 }(23.6 \%) \\
\text { IVSI-110 (29.5\%) }\end{array}$ & {$[32,41,42]$} \\
\hline Northeast of Iran & & & IVS-I-5 (42.03\%) & {$[43]$} \\
\hline Central regions of Iran & Hb-D (75.67\%) & & & {$[44]$} \\
\hline West of Iran & & & $\begin{array}{l}\text { CD36/37 (33.8\%) } \\
\text { IVSII-1 (33\%) }\end{array}$ & {$[14,45]$} \\
\hline Southwest of Iran & $\operatorname{HbS}(21.0 \%)$ & $-3.7 \alpha(20.0 \%)$ & $\begin{array}{l}\text { IVSII-1 (11.7\%) } \\
\text { CD36/37 (13.9\%) }\end{array}$ & {$[15,16,30]$} \\
\hline South of Iran & & & IVSI-5 $(69 \%)$ & {$[46]$} \\
\hline
\end{tabular}

than $90 \%$ of mutations were $\alpha^{+}$and just $6.3 \%$ were $\alpha^{0}$ phenotypes. The more often $\alpha^{+}$mutations were -3.7 , $-\alpha$, Polly A2, and -med accounts for more than $95 \% \alpha 0$ mutations (Table 5). The most frequent genotype in alphathalassemia carriers was $-3.7 / \alpha \alpha(52.2 \%)$; this is in accordance with findings of Keikhaei et al.'s study [19]. Our results are in agreement with data obtained from similar studies conducted by some researchers in Iran, Turkey, and Israel, where -3.7 mutation is the most frequent defected gene [30-35], whereas the conducted studies in Malaysia and China revealed that the -SEA mutation has the most prevalent [36, 37].

Further analysis showed that the severity of alphathalassemia is less than beta and alpha-beta thalassemia (Table 2), and the significant reduction was not found in $\mathrm{HbA} 2$ and $\mathrm{HbF}$ in alpha thalassemia carriers compared with normal subjects. This result may be explained by the fact that there are four copy numbers of the alphaglobin gene in normal individuals, encoded by two adjacent homologous genes, alpha 1 and alpha 2; these units were divided into $\mathrm{X}, \mathrm{Y}$, and $\mathrm{Z}$ homologous units [4]. The recombination of $Z$ units causes developing the rightward deletion $(-3.7 \alpha)$, which is accountable for the most frequent NDMs [3]. Additionally, there is no compensatory increase in the remaining functional gene, which causes producing unstable $\mathrm{Hb}$ and reduction of $\mathrm{Hb}$ [3]. The severity of alpha thalassemia is somewhat proportional to the number of affected alpha alleles. Sometimes thalassemic erythrocytes produce more alpha chains than predicted by the number of affected alleles. There are two possible explanations for this. First, the alpha 2-gene produces two or three times the amount of mRNA than the alpha1-gene [38, 39]; therefore, the mutation in the alpha 2-globin gene would reduce two up to three times in alpha-chain production [3, 39]. Second, erythrocytes have an internal mechanism to compensate for deleted genes that stimulate the more production of alpha chains from the unaffected genes. Depending on the amount of the involved alpha gene, exceeds beta-chains accumulate and combine as a tetramer $(\beta 4)$.

\section{Geographical distribution of thalassemia and hemoglobinopathies in Iran}

Despite its great clinical success in the premarital diagnosis of thalassemia, 3 to 100 patients per 100,000 are the carriers for thalassemia in Iran [40]. A considerable amount of literature has been published about the type of thalassemia, mutations, and their influence on the phenotype of thalassemia in Iran, but these contradictory findings show the distribution of thalassemia and hemoglobinopathies entirely dependent on the geographical distribution. Table 6 , shows the molecular spectrum and hemoglobinopathies in different provinces according to the comprehensive investigations. As shown in Table 6, the most reported mutation in beta gene was IVSII-I [13, 15, 16, 30, 41, 42]. After hemoglobinopathies frequency analysis, more prevalence of $\mathrm{HbS}$ and $\mathrm{HbD}$ was reported in southwestern and central regions of Iran, respectively [16, 44]. As discussed earlier, the results obtained from previous studies about alpha thalassemia mutations showed that most of them are in agreement that $-3.7 \alpha$ is the most frequent alpha gene defect (Table 6).

\section{Limitations}

The current study is limited by the lack of positive samples for $\delta$ hemoglobinopathies, so further investigation and experimentation for $\delta$ hemoglobinopathies are strongly recommended. The data recorded in this study belonged only to those who met the inclusion criteria, and lack of access to the initial number of subjects is another limitation of the study.

\section{Conclusion}

This study set out to determine the most frequent type of thalassemia, mutations, and their association with hematological parameters in the Khuzestan Province, southwest of Iran. Previously published studies are limited to investigating just 
one type of thalassemia or evaluating the low sample size in Khuzestan $[18,19]$. The result of this study showed that alpha thalassemia is more frequent and is accompanied by a slight to mild phenotype. According to our findings, the normal level of $\mathrm{HbA} 2$ and $\mathrm{HbF}$ cannot rule out alpha thalassemia. This study, by providing comprehensive data about all types of thalassemia frequency and indicating the prevalence of thalassemia carriers with normal electrophoresis, can be more helpful in preventing thalassemia.

Acknowledgments We wish to thank all our colleagues at the Allied Health Sciences School, Ahvaz Jundishapur University of Medical Sciences.

Author contributions F.R conceived the manuscript and revised it. M. A and J.M.A wrote the manuscript and prepared tables and figures.

\section{Compliance with ethical standards}

Competing interests The authors declare that they have no conflict of interest.

Ethical approval This article was approved by the sponsor and the applicant with respect to scientific content and compliance with applicable research and human subjects' ethical regulations.

Informed consent For this type of study, informed consent was not required.

\section{References}

1. Weatherall DJ (2010) The inherited diseases of hemoglobin are an emerging global health burden. Blood 115(22):4331-4336

2. Galanello R, Cao A (2011) Alpha-thalassemia. Genet Med 13(2): 83-88

3. Mettananda S, Higgs DR (2018) Molecular basis and genetic modifiers of thalassemia. Hematol Oncol Clin North Am 32(2):237-245

4. Harteveld CL et al (2010) A-thalassaemia. Orphanet J Rare Dis $5(1): 13$

5. Al-Amodi AM et al (2018) Hemoglobin A2 (HbA2) has a measure of unreliability in diagnosing $\beta$-thalassemia trait $(\beta-\mathrm{TT})$. Curr Med Res Opin

6. Borges E, Wenning MRSC, Kimura EM, Gervásio SA, Costa FF, Sonati MF (2001) High prevalence of $\alpha$-thalassemia among individuals with microcytosis and hypochromia without anemia. Brazilian J Med Biol Res

7. Sarookhani MR, Asiabanha M (2011) Spectrum of [alpha]-thalassemia mutations in Qazvin Province, Iran. African J Biotechnol 10(77):17690-17694

8. Celik MM, Gunesacar R, Oktay G, Duran GG, Kaya H (2013) Spectrum of $\alpha$-thalassemia mutations including first observation of - -fil deletion in Hatay province, Turkey. Blood Cells Mol Dis 51(1):27-30

9. Cai W-Q, Hu X-J, Xiong Q, Zhou B (2018) Prevalence and genotype analysis of newborn $\alpha$-thalassemia in Wuhan area of China. Zhongguo Shi Yan Xue Ye Xue Za Zhi 26(1):219-222

10. Baysal E (2011) $\alpha$-Thalassemia syndromes in the United Arab Emirates. Hemoglobin
11. Akhavan-Niaki H et al (2011) A comprehensive molecular characterization of beta thalassemia in a highly heterogeneous population. Blood Cells Mol Dis

12. Najmabadi H et al (2006) Fourteen-year experience of prenatal diagnosis of thalassemia in Iran. Community Genet

13. Derakhshandeh-Peykar P, Akhavan-Niaki H, Tamaddoni A, Ghawidel-Parsa S, Naieni KH, Rahmani M, Babrzadeh F, Dilmaghani-Zadeh M, Farhud DD (2007) Distribution of $\beta$ thalassemia mutations in the northern provinces of Iran. Hemoglobin 31(3):351-356

14. Kiani AA, Mortazavi Y, Zeinali S, Shirkhani Y (2007) The molecular analysis of $\beta$-thalassemia mutations in Lorestan Province, Iran. Hemoglobin

15. Dehghanifard A et al (2013) Prenatal diagnosis of different polymorphisms of $\beta$-globin gene in Ahvaz. Int J Hematol Stem Cell Res

16. Saki N, Dorgalaleh A, Kashani Khatib Z, Alizadeh S, Rahim F, Galehdari H et al (2013) Prevalence of co-inheritance of alphathalassemia with beta-thalassemia and beta-hemoglobinopathy in Ahvaz City. J Ardabil Univ Med Sci 13(3):287-296

17. Rahimi Z (2013) Genetic epidemiology, hematological and clinical features of hemoglobinopathies in Iran. Biomed Res Int

18. Rahim F, Kaikhaei B, Zandian K, Hoseini A (2008) Co-inheritance of (alpha)-and (beta)-thalassemia in Khuzestan Province, Iran. Hematology 13(1):59-64

19. Keikhaei B, Slehi-fard P, Shariati G, Khosravi A (2018) Genetics of Iranian alpha-thalassemia patients: a comprehensive original study. Biochem Genet:1-16

20. Hashemizadeh H, Noori R (2013) Premarital screening of Beta thalassemia minor in north-east of Iran. Iran J Pediatr Hematol Oncol

21. Tosun F, Bilgin A, Kizilok A, Arpaci A, Yüreğir GT (2006) Fiveyear evaluation of premarital screening program for hemoglobinopathies in the province of Mersin, Turkey. Turkish J Hematol

22. Rahiminejad MS, Zeinali S, Afrasiabi A, Kord Valeshabad A (2011) $\beta$-Thalassemia mutations found during 1 year of prenatal diagnoses in Fars province, Iran. Hemoglobin

23. Maryami F, Azarkeivan A, Fallah MS, Zeinali S (2015) A large cohort study of genotype and phenotype correlations of betathalassemia in Iranian population. Int J Hematol Stem Cell Res 9(4):198-202

24. He S, Li J, Li DM, Yi S, Lu X, Luo Y, Liang Y, Feng C, Chen B, Zheng C, Qiu X (2018) Molecular characterization of $\alpha$ - and $\beta$ thalassemia in the Yulin region of southern China. Gene 655:61-64

25. Tang W, Zhang C, Lu F, Tang J, Lu Y, Cui X, Qin X, Li S (2015) Spectrum of $\alpha$-thalassemia and $\beta$-thalassemia mutations in the Guilin region of southern China. Clin Biochem 48(16-17):10681072

26. Mettananda S, Gibbons RJ, Higgs DR (2015) $\alpha$-Globin as a molecular target in the treatment of $\beta$-thalassemia. Blood 125(24): 3694-3701

27. Voon HP, Vadolas J (2008) Controlling alpha-globin: a review of alpha-globin expression and its impact on beta-thalassemia. Haematologica

28. Thein SL 2013 "Genetic association studies in $\beta$-hemoglobinopathies.," Hematology/the Education Program of the American Society of Hematology. American Society of Hematology. Education Program

29. Fucharoen S and Viprakasit V 2009 "Hb H disease: clinical course and disease modifiers.," Hematology / the Education Program of the American Society of Hematology. American Society of Hematology. Education Program

30. Rahim F (2008) Genotyping of thalassemia in microcytic hypochromic anemia patients from southwest region of Iran. Pakistan J Med Sci

31. Doosti Irani A, Cheraghi Z, Bitaraf S, Cheraghi P, Safiri S (2015) Prevalence of alpha and beta-thalassemia mutations among carriers 
of thalassemia in Shadegan City, southwest of Iran. Zahedan J Res Med Sci 17(8)

32. Derakhshan SM, Khaniani MS, Afkhami F, PourFeizi AH (2016) Molecular study of deletional and nondeletional mutations on the $\alpha$-globin locus in the Azeri population of northwestern Iran. Hemoglobin

33. Bozdogan ST, Yuregir OO, Buyukkurt N, Aslan H, Ozdemir ZC, Gambin T (2015) Alpha-thalassemia mutations in Adana Province, southern Turkey: genotype-phenotype correlation. Indian $\mathrm{J}$ Hematol Blood Transfus

34. Tamaddoni A, Hadavi V, Nejad NH, Khosh-Ain A, Siami R, AghaiMeibodi J, Almadani N, Oberkanins C, Law HY, Najmabadi H (Jan. 2009) $\alpha$-Thalassemia mutation analyses in Mazandaran province, North Iran. Hemoglobin 33(2):115-123

35. Oron-Karni $V$ et al (2000) Diversity of $\alpha$-globin mutations and clinical presentation of $\alpha$-thalassemia in Israel. Am J Hematol

36. Yin A et al (2014) The prevalence and molecular spectrum of $\alpha$ and $\beta$-globin gene mutations in 14,332 families of Guangdong Province, China. PLoS One

37. Wee YC et al (2008) Alpha-thalassaemia in association with betathalassaemia patients in Malaysia: a study on the co-inheritance of both disorders. Publ Health Genomics 11(3):129-134

38. Shakin SH, Liebhaber SA (1986) Translational profiles of alpha 1-, alpha 2-, and beta-globin messenger ribonucleic acids in human reticulocytes. J Clin Invest 78(4):1125-1129

39. Farashi S, Harteveld CL (2018) Molecular basis of $\alpha$-thalassemia. Blood Cells Molecules Dis 70:43-53
40. Abolghasemi H et al (2007) Thalassemia in Iran: epidemiology, prevention, and management. J Pediatr Hematol Oncol 29(4): 233-238

41. Mortazavi Y, Taheri S, Derakhshandeh J, Zeinali S (2008) Characterization of beta globin gene mutations in Zanjan Province: an introduction to prenatal diagnosis of thalassemia. 66(1):51-57

42. Derakhshan SM, Khorrami A (2015) Spectrum of $\beta$-globin gene mutations and $\beta$-thalassemia haplotype analysis among the Iranian Azeri Turkish population. Epidemiol Open Access 05(04)

43. Jaripour ME et al (2018) Mediterranean journal of hematology and infectious diseases prevalence of $\beta$-thalassemia mutations among northeastern Iranian population and their impacts on hematological indices and application of prenatal diagnosis, a seven-years study. Mediterr J Hematol Infect Dis 10(1):2018042

44. Ashtiani MTH et al (2009) Prevalence of haemoglobinopathies in 34030 healthy adults in Tehran, Iran. J Clin Pathol

45. Rahimi $\mathrm{Z}$ et al (2009) Haplotype analysis of beta thalassemia patients in Western Iran. Blood Cells Mol Dis

46. Yavarian M, Harteveld CL, Batelaan D, Bernini LF, Giordano PC (2001) Molecular spectrum of $\beta$-thalassemia in the Iranian Province of Hormozgan. Hemoglobin

Publisher's note Springer Nature remains neutral with regard to jurisdictional claims in published maps and institutional affiliations. 